\title{
Genetic Diversity And Population Structure of Zymoseptoria Tritici Populations of Southern Ethiopia Using SSR Markers
}

\author{
Messele Molla Kassia ( $\nabla$ messelemolla@gmail.com ) \\ National Agricultural Plant Biotechnology Research Center \\ Kasahun Tesfaye \\ Ethiopian Biotechnology Institute \\ Teklehaimanot Haileselassie \\ Addis Ababa University \\ Tilahun Mekonnen \\ Addis Ababa University \\ Obssi Dessalegn \\ National Agricultural Plant Biotechnology Research Center
}

\section{Research Article}

Keywords: Alleles, Genetic Structure, Microsatellites, Wheat

Posted Date: January 28th, 2022

DOI: https://doi.org/10.21203/rs.3.rs-1219646/v1

License: (c) (i) This work is licensed under a Creative Commons Attribution 4.0 International License. Read Full License 


\section{Abstract}

The fungal disease Zymoseptoria tritici causes Septoria tritici blotch, which is one of the most serious challenges to wheat production in Ethiopia and around the world. Understanding the pathogen's genetic structure is critical for developing and implementing effective management methods. Therefore, the present study targeted to explore the genetic structure of $51 Z$. tritici isolates collected from four wheat producing zones of South and Southwestern parts of Ethiopia using nine microsatellite markers. In all of the examined isolates, a $Z$. tritici specific diagnostic marker that targets the ITS rDNA had amplified a predicted fragment size of 345bp. The number of alleles, gene diversity, and polymorphic information content per locus ranged from 9 to $14,0.80$ to 0.88 , and 0.70 to 0.87 , respectively, indicating a significant degree of genetic variety within populations. The results of an analysis AMOVA revealed a moderate (0.14) genetic differentiation, with 86 percent of total genetic variability (3.93) occurring within populations. Due to the existence of considerable gene flow, the dendrogram produced by UPGMA and PCoA also revealed a moderate population clustering in which the populations were not clearly clustered according to their sample areas.

Furthermore, population structure analysis using a Bayesian model loosely grouped the population into five (K) sub-groups with substantial genetic mixing. The populations of the Kembata-Tembar and Hadiya zone have higher genetic variability than the other populations studied, and hence can be considered STB hot sites for future research on pathogen dynamics, germplasm screening, and host-pathogen interactions.

\section{Introduction}

Wheat is the third most widely produced cereal crop in the world next to maize (Zea masys L.) and rice (Oryza sativa L.). It is the fourth most important staple crop in Ethiopia after Tef (Eragrostis tef), Maize (Zea mays) and Sorghum (Sorghum bicolor) Next to South Africa; Ethiopia is the second largest wheat producer in Sub-Saharan Africa (Letta et al. 2013). Both bread wheat (Triticum aestivum L.) and durum wheat (Triticum turgidumssp. durum L.) are widely cultivated in Ethiopia for multiple purposes including food, feed and income generation (Dixon et al. 2006). In 2017, about $1.7 \mathrm{M}$ ha of land was covered with wheat and the national annual production and productivity were 4.8million metric tonnes and $2.8 \mathrm{t} / \mathrm{ha}$, respectively (FAOSTAT, 2018). The potential wheat growing regions of the country includes Oromiya, Amhara, Tigray and Southern Nations Nationalities and Peoples region (SNNPR). In spite of its larger production coverage and multiple uses, the average productivity of wheat in Ethiopia is 2. $8 \mathrm{t} /$ ha; which is by below the global average of $3.27 \mathrm{t} /$ ha (Alemar Said and Temam Hussien, 2016).

Septoria tritici blotch (STB) caused by the ascomycete Mycosphaerella graminicola (asexual stage: Zymoseptoria tritici) is the major wheat devastating fungal disease next to rust in Ethiopia ( Abera Takele et al. 2015; Tilahun Mekonnen et al. 2019; 2020) and elsewhere in the world (Eyal et al. 1985). Under favorable growing conditions with high relative humidity (85\%) and optimal temperature $\left(22^{\circ} \mathrm{C}\right)$, STB could decrease yield by 30 to $70 \%$ (Eyal et al. 1987). The disease is mainly a foliage disease and the primary infection may arise from airborne or rain splashed asexual pycnidospores and sexual ascospores from infested crop debris (Shaner, 1981; Gilchrist and Dubin, 2002). Changes in farming practices (higher sowing densities and nitrogen fertilization), mono cropping system and limited number of cultivars contributed significantly to the increase of the disease (Berraies et al. 2013). In Ethiopia up to 82\% wheat yield loss has been reported (Mengistu Huluka et al. 1991; Abreham Tadesse, 2008). STB is becoming serious problem in southern and southwestern part of Ethiopia including Haddiya, Kambata, Silte and Southwest Shewa (Alemar Said and Temam Hussien, 2016). Integrated disease management strategies including genetic resistance (resistant varieties), crop rotation, appropriate fertilizer and fungicide applications, proper seeding rates and dates would be alternatives to control STB disease (Berraies et al. 2013). Genetic resistance remains the first line of defense against this foliar disease, especially in developing countries for resource poor farmers, and is the most environmentally friendly and profitable strategy for farmers (Teklay Abebe et al. 2015). However, in Ethiopia most of the high-yielding wheat cultivars grown today are susceptible to STB. All commercial and candidate wheat varieties are affected by the disease at varying intensity (Alemar Said and Temam Hussien, 2016). This calls for searching for new source of resistance to the diseases. In this regard, knowledge of the genetic diversity of the pathogen could have direct implications for development of effective and durable disease management strategies (Schnieder et al. 2001)

So far, different molecular marker systems have been used to explore the genetic structure of $Z$. tritici populations including Sequence Characterized Amplified Region (SCAR), simple sequence repeats (SSRs), restriction fragment length polymorphisms

Page 2/19 
(RFLPs), amplified fragment length polymorphisms (AFLPs) and Rapid amplified polymorphic DNAs (RAPDs) (Schnieder et al. 2001). Simple sequence repeats (SSRs) also called microsatellites are considered to be the marker of choice for assessing genetic diversity of population as they are co-dominant, easy to use, highly polymorphic, multiallelic, locus specific, and highly reproducible (Czembor and Arseniuk, 1999).

In breeding for disease resistance cultivars, knowledge of pathogen's genetic diversity has a great importance (Sebei and Harrabi, 2008). However, information on the pathogen's geographic distribution and genetic diversity in Ethiopia is limited. By considering the greater efficiency and speed of SSR markers, this research aimed to use them to study genetic diversity of $Z$. tritici from southern part of Ethiopia.

In Ethiopia, Tilahun Mekonnen et al. (2020) used SSR markers to explore the genetic diversity of Z. tritici populations of central highlands and south eastern parts of Ethiopia and confirmed the existence of higher genetic diversity among the pathogen populations. However, information on the genetic structure of the pathogen populations of Southern Ethiopia is lacking. Therefore, the present study was designed to assess the molecular diversity of Zymoseptoria tritici populations collected from southern part of Ethiopia to generate useful baseline information for the development of durable Septoria resistant cultivars.

\section{Materials And Methods Description of the Study Area}

The Z. tritici isolates used in this study were isolated from STB symptomatic wheat leaf samples collected from naturally infected wheat fields of three zones (Kembata- tembaro, Hadiya, Silite) of the SNNPR state, and one bordering zone i.e Southwest Shewa zones from Oromia in 2018 main cropping season (Fig. 1). The zones were selected based on their wheat production potentials in Southern part of Ethiopia. From each zone, Woreda /District and Kebels (the lowest local administration) were subsequently selected based on their wheat production potential and road accessibility.

Table 1

Description of areas from where samples of Zymoseptoria tritici were collected.

\begin{tabular}{|lllll|}
\hline Study area & Longitude & Latitude & Altitude (m.a.s.l.) & Temperature $\left({ }^{\circ} \mathrm{C}\right)$ \\
\hline Kembata- tembaro, & $37^{\circ} .34^{\prime \prime}-38^{\circ}$ & $7^{\circ} .10^{\prime \prime}-7^{\circ} .50^{\prime \prime}$ & $501-3000$ & $126-27.5$ \\
\hline Hadiya & $37^{\circ} 23^{\prime} 14^{\prime \prime}-38^{\circ} 52^{\prime} 13^{\prime \prime}$ & $7^{\circ} 3^{\prime} 19^{\prime \prime}-7^{\circ} 56^{\prime} 1^{\prime \prime}$ & $1500-3000$ & $10-35$ \\
\hline Silite & $38^{\circ} 16^{\prime} 60^{\prime \prime}$ & $7^{\circ} 58^{\prime} 0^{\prime \prime}$ & 2317 & $10-35$ \\
\hline Southwest-Shewa & $37^{\circ} 05^{\prime}-38^{\circ} 46^{\prime}$ & $8^{\circ} 16-90^{\prime} 56^{\prime \prime}$ & $1600-3576$ & $10-35$ \\
\hline
\end{tabular}

\section{Sample Collection}

STB symptomatic wheat leaf samples were collected from naturally infected wheat fields (Fig. 5) from the four zones at the beginning of October in 2018 main cropping season following the main roads and accessible routes at 5-10 km intervals based on vehicle odometers. Hundred samples were collected at medium milk and early dough growth stages (GS) as described by Zadoks et al. (1974). We have visited about 120 naturally grown wheat fields and 0.83 average samples were collected from each field.

During collection, green leaf samples in the wheat field naturally infected with STB with black spots (pycnidia) on the necrosis area were collected. Scissors were swiped with $70 \%$ ethanol prior to the next sample collection to avoid cross contamination. Collected samples were placed in paper envelopes, and followed by recording of collection date, sample code, latitude, longitude, altitude, and disease severity score. The samples were left to dry at room temperature for a week, and then were placed in zipped plastic bag and stored at $5^{\circ} \mathrm{C}$ until isolation begins.

\section{Diagnostic and Disease Assessment in the Field}


Diagnosis of the disease on wheat is based on the observation of the typical symptom caused by $Z$. tritici. The STB was identified by chlorotic spots and light tan lesions with small blackings (Ponomarenko et al. 2011). Disease severity was scored based on double digit scale (00-99) where the first digit (0-9) indicates the necrotic leaf area on the four uppermost infected leaves of 10 - 20 plants and the second 0-9 digit represent the blotch development up the plant height (for instance 5 if the disease reached at the middle (50\%) of the plant height, 8 for flag leaf and 9 for spike), and the second digit stands for disease severity as a percentage but in terms of $0-9(1=10 \%, 2=20 \% \ldots$ and $9=90 \%)$. Depending on the size of the wheat field three to five stops were made in an " $X$ " pattern and average result was taken to describe the disease severity of the field (Eyal et al. 1987)

\section{Isolation of Septoria tritici Pathogen}

Isolation of Zymoseptoria tritici fungal spore and following activities were conducted at National Agricultural Biotechnology Research Center (NABRC), Holeta, $29 \mathrm{Km}$ west of the capital city- Addis Ababa. The isolation was carried out as described by Eyal et al. (1987) with some modifications. During isolation a necrotic wheat leaf with a pycnidium was placed on wet filter paper in Petri dish (Fig. 2a) at room temperature $\left(20-25^{\circ} \mathrm{C}\right)$ for four hours. Under high humidity ooze that contains pycnidiospores were emerged from the opening of the pycnidium (ostiole) and formed a drop (cirrhus) on top of the dark pycnidium. Observing under stereoscopic dissecting microscope (Fig. 2b), mono-pycnidial oozing drops were transferred onto potato dextrose agar plate (PDA) containing $250 \mathrm{mg} / \mathrm{l}$ chloramphenicol succinate using flame sterilized needle. Inoculated Petri plates were kept at $24^{\circ} \mathrm{C}$ for 10 days until fungal growth was observed. Developed pinkish-orange colony was streaked on a new PDA plates without antibiotics and kept at the same conditions.

Developed mono-spore derived colonies (Fig. 2c) were transferred to yeast-sucrose broth (YSB) (1\% sucrose, 1\% yeast extract) and incubated at room temperature on orbital shaker $(180 \mathrm{rpm})$ for two weeks for spore multiplication (Fig. 2e). Spore pellets were recovered (Fig. 2f) by centrifugation at $10,000 \mathrm{rpm}$ for 5 minutes and stored at $-80^{\circ} \mathrm{C}$ until used for DNA extraction. For long term storage fungal isolates were preserved in yeast extract $(4 \mathrm{~g} / \mathrm{l})$, malt extract $(4 \mathrm{~g} / \mathrm{l})$, and sucrose $(4 \mathrm{~g} / \mathrm{l})$, supplemented with $30 \%$ glycerol and stored at $-80^{\circ} \mathrm{C}$

\section{Assessing the Genetic Diversity of Zymoseptoria tritici isolates}

\section{Genomic DNA isolation}

Fungal genomic DNA isolation was carried out using diversity array technology (DArT) with minor modification. The DNA was quantitatively and qualitatively checked using a Nano drop spectrophotometer (ND-1000) and gel- electrophoresis. DNA concentration was adjusted to $50 \mathrm{ng} / \mu \mathrm{l}$ using sterile nuclease free water and stored at $-20^{\circ} \mathrm{C}$ for further use.

\section{Molecular detection of Zymoseptoria tritici}

All 51 isolates were confirmed by running polymerase chain reaction (PCR) using a race specific diagnostic markers ITS1 (5'TCCGTAGGTGAACCTGCGG-3') as forward and JB446 (5'CGAGGCTGGAGTGGTGT-3') as reverse primer (Beck and Ligon 1995). The PCR reaction was performed in a volume of $12.5 \mu$ l containing $6.25 \mu \mathrm{l}(2 \mathrm{x}$ Taq plus master mixes), $2 \mu \mathrm{l}$ Nuclease free water, $1 \mu \mathrm{l}$ of each of the forward (ITS1) and reverse (JB446) primers and $2.5 \mu \mathrm{l}$ of $50 \mathrm{ng}$ template DNA. Amplification conditions were set as an initial denaturation at $94^{\circ} \mathrm{C}$ for 3 min followed by 35 cycles with 1 min denaturation at $94^{\circ} \mathrm{C}, 1$ min annealing at $60^{\circ} \mathrm{C}$, primer extension at $72 \mathrm{C}$ for 2 min followed by final extension step of $10 \mathrm{~min}$ at $72^{\circ} \mathrm{C}$. The PCR amplified products were fractionated in $3 \%$ agarose gel electrophoresis by loading $5 \mu$ l of each of the PCR product mixed with $2 \mu$ l of loading dye with $1 x$ gel red using 1x TAE buffer at 100V for three hours. Amplicon fragment size was estimated using 100 bp DNA molecular ladders. The gel was visualized and also photographed using gel-documentation system (BioDoc-lt ${ }^{\mathrm{TM}}$ imaging system).

\section{SSR marker based genotyping}

For molecular diversity and population structure analysis, the confirmed Z. tritici isolates were genotyped using nine published single locus microsatellite primers as described by (Owun et al. 1998 and Berraies et al. 2013) (Table 2). 
Table 2

SSR markers and their respective primers used for genotyping of $Z$. tritici isolates.

\begin{tabular}{|c|c|c|c|c|c|}
\hline Marker & $\begin{array}{l}\text { Repeat } \\
\text { Motif }\end{array}$ & $\begin{array}{l}\text { Annealing } \\
\text { temperature } \\
\left({ }^{\circ} \mathrm{C}\right)\end{array}$ & $\begin{array}{l}\text { Expected } \\
\text { Size (bp) }\end{array}$ & Forward & Reverse \\
\hline $\begin{array}{l}\text { ST1E7 } \\
\text { (MGR } \\
7038)\end{array}$ & (CGG) 5 & 58 & $85-91$ & 5'GATCTCGAGCAGGGCGGAAGT3' & 5'TCACACGCTGGTCTGTGAATC3' \\
\hline $\begin{array}{l}\text { ST2E4 } \\
\text { (MGR } \\
7034)\end{array}$ & $(\mathrm{GGC}) 5$ & 58 & 75 & 5'GAAGATCAACAGCATGGGCGG3' & 5'CTCCAGAGGGATCACAAAGGC3' \\
\hline $\begin{array}{l}\text { ST1A4 } \\
\text { (MGR } \\
7032)\end{array}$ & $(\mathrm{CCG}) 7$ & 58 & $98-116$ & 5'GGTTCGATGGAGAGATTT3' & 5'TCAССТССТСАTCGCAGA3' \\
\hline $\begin{array}{l}\text { ST1D7 } \\
\text { (MGR } \\
7039)\end{array}$ & (AC)22 & 61 & $85-105$ & 5'TTGAAGTGGCATCCTCCATT3' & 5'AACTCGGCTGGTGGAACA3' \\
\hline $\begin{array}{l}\text { ST2C10 } \\
\text { (MGR } \\
7036)\end{array}$ & $(\mathrm{AGCGG}) 4$ & 58 & $75-87$ & 5'AGGCGAGAAACTTGCTTGCAG3 & 5'AATGAACGTCCCATGGACGTG3' \\
\hline $\begin{array}{l}\text { AG- } \\
0003\end{array}$ & $(A G) 15$ & 52 & $230-258$ & $\begin{array}{l}5{ }^{\prime} \text { ACT TGG GGA GGT GTTGTA AG } \\
3^{\prime}\end{array}$ & $\begin{array}{l}\text { 5' ACT TGG GGA GGT GTT GTA } \\
\text { AG } 3^{\prime}\end{array}$ \\
\hline $\begin{array}{l}\text { AC- } \\
0001\end{array}$ & $(\mathrm{AC}) 7$ & 52 & $171-200$ & 5'CACCACCAC GTGGTTGAA G 3' & $\begin{array}{l}5{ }^{\prime} \text { CGTAAG TTC GTG GAG ATG GG } \\
3^{\prime}\end{array}$ \\
\hline $\begin{array}{l}\text { AG- } \\
0009\end{array}$ & $(\mathrm{AG}) 7$ & 52 & $192-200$ & $\begin{array}{l}\text { 5' C GAC TGC ATTTACTTGTGG } \\
\text { CG 3' }\end{array}$ & 5'TGTGAAGG CAC GCAAAG AG 3' \\
\hline $\begin{array}{l}\text { AC- } \\
0002\end{array}$ & $(\mathrm{AC}) 7$ & 52 & $172-210$ & $\begin{array}{l}5^{\prime} \text { TGA ACA TCA ACC TCA CAC GC } \\
3^{\prime}\end{array}$ & $\begin{array}{l}5^{\prime} \text { ACAAGA GGA CGACCCACGAC } \\
3^{\prime}\end{array}$ \\
\hline
\end{tabular}

PCR was performed in a total volume of $12.5 \mu$ l containing $6.25 \mu$ master mix, $2 \mu$ l DNA tamplate, $1 \mu$ l of each of the forward and reverse primers, $0.25 \mu \mathrm{l}$ DMSO and $2 \mu \mathrm{l}$ nuclease free water. PCR amplification was conducted on a Biometra thermocycler program as follows: $3 \mathrm{~min}$ at $94^{\circ} \mathrm{C}$ for initial denaturation followed by 40 cycles of denaturation at $94^{\circ} \mathrm{C}$ for $1 \mathrm{~min}$, annealing at $52-65^{\circ} \mathrm{C}$ for $1 \mathrm{~min}$, and extension at $72^{\circ} \mathrm{C}$ for $2 \mathrm{~min}$. The final extension was adjusted to at $72^{\circ} \mathrm{C}$ for $10 \mathrm{~min}$. PCR products were resolved on $3 \%$ agrose gels electrophoresis using $1 \times$ TAE buffer at $100 \mathrm{~V}$ for $3 \mathrm{~h}$. The gel was stained with gel red and visualized under UV light and subsequently photographed. To estimate the amplicon size A 50 Bp and $100 \mathrm{Bp}$ DNA ladder were used.

\section{Data scoring and statistical analysis}

The PCR amplified SSR regions fragment size on gel were estimated using PyElph 1.4 software package (Pavel and Vasile, 2012). Genetic diversity analyses were carried out on the basis of the scored bands. Only clearly resolved and unambiguous bands were scored for each primer and sample. For each locus, amplified fragments with different molecular sizes were considered as different alleles. Appropriate statistical software packages were employed to compute the standard indices of genetic diversity. Locus based diversity indices including major allele frequency (MAF), the number of allele ( $\mathrm{Na}$ ), and gene diversity(GD) and Polymorphic information contents (PIC) were computed using Powermarker v3.25 software (Liu and Muse, 2005). Effective number of alleles (Ne) and Shannon's Information index (I) were determined using POPGENE version 1.31(Yeh and Yang, 1999). Allelic frequency and population genetic structure and differentiation among and within isolates based on their geographic origin and the analysis of molecular variance was performed using GenAlEx ver. 6.503 software (White and Peakall, 2015).

The patterns of variation among individual samples and highlight the resolving power of ordination was examined by PCOA. The weighted neighbor joining based clustering and relative position of genotypes on principal coordinate axis (PCoA) was computed by GenAlex version 6.503 (White and Peakall, 2015). 
Genetic dissimilarity (GD) between isolates was calculated according to the formula of Nei (1973). The UPGMA (unweighted pair-group method with arithmetic averages) clustering method was used to obtain the dendrogram using DARwin var. 6.0.14 (Perrier and Jacquemoud-Collet, 2006).

Population structure and admixture patterns were determined using STRUCTURE software ver. 2.3.4 based on Bayesian algorithm (Pritchard et al. 2000). To estimate the true number of population cluster (K), a burn-in period of 100,000 was used in each run, and data were collected over 200,000 Markov Chain Monte Carlo (MCMC) replications for $\mathrm{K}=1$ to $\mathrm{K}=9$ using 20 iterations for each $\mathrm{K}$. The most likely number of $\mathrm{K}$ was determined based on Evanno correction (Evanno et al. 2005) method using the web-based STRUCTURE HARVESTER ver. 0.6.92 (Earl and Von Holdt, 2012). Bar plot for the optimum K was determined using Clumpak beta version (Kopelman et al. 2015).

\section{Results}

\section{Molecular Based Identification of Zymoseptoria tritici}

Conserved regions of the ribosomal DNA (ITS-derived primers) were used to amplify specific fragments from the isolates for the detection of $Z$. tritici species. Diagnostic analysis using a pair of primers (ITS and JB446) revealed that all the 51 tested $Z$. tritci isolates resulted in positive unambiguous amplification of the expected fragment size of about $345 \mathrm{bp}$. This confirms that all the morphologically identified study materials are Zymoseptoria tritici and considering their molecular diversity is thus important.

\section{Molecular Diversity Analysis}

\section{Microsatellite markers level of polymorphism}

The analysis revealed that all the nine loci were found to be polymorphic and produced a total of 439 bands with an average of 48.77 bands per locus (Table 4). The highest number (51) of bands per locus was recorded for AG-0003 marker, out of which 48 (94.11\%) were polymorphic. The highest (95.65\%) percentage of polymorphic bands was produced by the locus ST1E7, followed by AG-003 and then AC-002 which resulted in $94.11 \%$ and $94 \%$ polymorphic bands, respectively. Five (55.56\%) of the considered SSR marker resulted in above average percentage of polymorphic bands. The lowest (90\%) percentages of polymorphic bands were exhibited by two SSR loci (ST2E4 and AC-0001) (Table 3). 
Table 3

Number of polymorphic bands, monomorphic bands and percentage of polymorphic bands produced by 9 SSR markers tested on 51 Z. tritici isolates.

\begin{tabular}{|lllll|}
\hline Primers & $\begin{array}{l}\text { Total no of } \\
\text { bands }\end{array}$ & $\begin{array}{l}\text { No Monomorphic } \\
\text { bands }\end{array}$ & $\begin{array}{l}\text { No of polymorphic } \\
\text { bands }\end{array}$ & $\begin{array}{l}\text { Percentage of polymorphic } \\
\text { bands }\end{array}$ \\
\hline $\begin{array}{l}\text { ST1E7 (MGR } \\
\text { 7038) }\end{array}$ & 46 & 2 & 44 & 95.65 \\
\hline $\begin{array}{l}\text { ST2E4 (MGR } \\
\text { 7034) }\end{array}$ & 50 & 5 & 45 & 90.00 \\
\hline $\begin{array}{l}\text { ST1A4 (MGR } \\
\text { 7032) }\end{array}$ & 49 & 4 & 45 & 91.83 \\
\hline $\begin{array}{l}\text { ST1D7 (MGR } \\
\text { 7039) }\end{array}$ & 49 & 3 & 46 & 93.87 \\
\hline $\begin{array}{l}\text { ST2C10 (MGR } \\
\text { 7036) }\end{array}$ & 45 & 3 & 42 & 93.33 \\
\hline AG-0003 & 51 & 3 & 48 & 94.11 \\
\hline AC-0001 & 50 & 5 & 45 & 90.00 \\
\hline AG-0009 & 49 & 4 & 45 & 91.83 \\
\hline AC-0002 & 50 & 3 & 47 & 94.00 \\
\hline Total & 439 & 32 & 407 & 92.71 \\
\hline
\end{tabular}

The study revealed that the number of alleles per locus varied from 9 to 14 with an average of 12 alleles per locus. The highest number of alleles (14) was resulted from two loci (ST2E4 and AG-0009). The analysis showed that $57 \%$ of the alleles were scarce (frequency between 0.01 and 0.05$)$. The frequency of $15(14 \%)$ alleles was between 0.05 and 0.1 , while $31(29 \%)$ alleles had a frequency of 0.1-1.00 (Table 4).

Table 4

Summary of the number of alleles with their respective frequencies

\begin{tabular}{|lllll|}
\hline Markers & \multicolumn{2}{l}{ Number of alleles with their respective frequencies } & Total \\
& \multicolumn{2}{l}{ Scarce(0.01-0.05) } & 0.05-0.1 & 0.1 and above \\
\hline ST1E7 (MGR 7038) & 6 & 4 & 1 & 11 \\
\hline ST2E4 (MGR 7034) & 10 & 1 & 3 & 14 \\
\hline ST1A4 (MGR 7032) & 5 & 3 & 3 & 11 \\
\hline ST1D7 (MGR 7039) & 10 & 0 & 2 & 12 \\
\hline ST2C10 (MGR 7036) & 4 & 3 & 4 & 11 \\
\hline Ag-0003 & 7 & 2 & 4 & 13 \\
\hline AC-0001 & 7 & 0 & 5 & 12 \\
\hline AG-0009 & 8 & 2 & 4 & 14 \\
\hline AC-0002 & 4 & 0 & 5 & 9 \\
\hline Total & 61 & 15 & 31 & 107 \\
\hline Percentage & $57 \%$ & $14 \%$ & $29 \%$ & $100 \%$ \\
\hline
\end{tabular}

The analysis showed that the major allele frequency per locus ranged from 0.18 (AG-0009) to 0.43 (ST1A4) with overall mean of 0.29 . The gene diversity (GD) ranged from 0.73 to 0.88 with an average of 0.82 . The highest gene diversity (0.88), polymorphic 
information content (0.87), number of alleles (14), effective number of alleles (4.605) and Shannon's Information Index (1.61) were recorded for the microsatellite locusAG-0009 (Table 5). On the other hand, the highest major allele frequency (0.43) and the lowest gene diversity (0.73), polymorphic information content (0.70) and Shannon's information index (0.96) were observed for primer ST1D7 (Table 5). The PIC values of all the SSR loci were found to be high $(>0.5)$ confirming their high informativeness (Table 5).

Table 5

Informativeness and levels of different diversity indices of 9 SSR markers across the entire $Z$. tritici populations.

\begin{tabular}{|llllllll|}
\hline Marker & N & MAF & GD & PIC & Na & Ne & I \\
\hline ST1E7 (MGR 7038) & 51 & 0.29 & 0.85 & 0.84 & 11 & 3.34 & 1.17 \\
\hline ST2E4 (MGR 7034) & 51 & 0.37 & 0.79 & 0.77 & 14 & 2.98 & 1.221 \\
\hline ST1A4 (MGR 7032) & 51 & 0.29 & 0.81 & 0.78 & 11 & 3.41 & 1.31 \\
\hline ST1D7 (MGR 7039) & 51 & 0.43 & 0.73 & 0.70 & 12 & 2.21 & 0.96 \\
\hline ST2C10 (MGR 7036) & 51 & 0.29 & 0.83 & 0.81 & 11 & 3.33 & 1.33 \\
\hline AG-0003 & 51 & 0.28 & 0.85 & 0.83 & 13 & 4.27 & 1.51 \\
\hline AC-0001 & 51 & 0.20 & 0.85 & 0.83 & 12 & 3.93 & 1.42 \\
\hline AG-0009 & 51 & 0.18 & 0.88 & 0.87 & 14 & 4.61 & 1.61 \\
\hline AC-0002 & 51 & 0.26 & 0.81 & 0.78 & 9 & 3.11 & 1.20 \\
\hline Mean & 51 & 0.29 & 0.82 & 0.80 & 12 & 3.47 & 1.30 \\
\hline
\end{tabular}

$\mathrm{MAF}=$ Major allele frequency, $\mathrm{N}=$ Number of samples, $\mathrm{NA}=$ Number of alleles, $\mathrm{Ne}=$ Effective number of alleles, $\mathrm{GD}=\mathrm{Gene}$ diversity and $\mathrm{PIC}=$ polymorphic information content.

\section{Genetic variability within and among the populations}

Summary of the different genetic diversity indices over the entire SSR loci for the four populations is presented in Table 5. The analysis showed the existence of high diversity among the four populations of $Z$. tritici with regard to number of alleles, effective number of alleles, genetic diversity, private allelic richness, Shannon's information index and percentage of polymorphic loci (Table 5). Among the studied populations, populations of Kembata- Tembaro scored greater values of number of alleles (6.78), effective number of alleles (4.15), genetic diversity (0.73) Shannon's information index (1.57) and private allelic richness (3.22) (Table 6). While isolates of Southwest Shewa showed lowest number of alleles (3.22), effective number of alleles (2.60) genetic diversity (0.57) and Shannon's information index (1.00) (Table 6). The analysis confirmed that all the studied populations showed $100 \%$ percentage of polymorphism. Based on the number of locally common alleles (Freq. $>=5 \%$ ) which is found in $50 \%$ or fewer populations, populations of Hadiya showed the highest value (2.11).

Table 6

Summary of different population diversity indices averaged over the 9 loci for each population.

\begin{tabular}{|lllllllll|}
\hline Population & N & Na & Ne & H & Arp & I & Na Freq. $>=5 \%$ & No. LComm Alleles (<=50\%) \\
\hline Kembata -Tembaro zone & 21 & 6.78 & 4.15 & 0.73 & 3.22 & 1.57 & 4.11 & 1.22 \\
\hline Hadiya zone & 17 & 6.67 & 4.38 & 0.73 & 2.11 & 1.63 & 6.67 & 2.11 \\
\hline Silite zone & 7 & 3.33 & 2.73 & 0.57 & 0.67 & 1.01 & 3.33 & 0.67 \\
\hline South west Shewa zone & 6 & 3.22 & 2.60 & 0.57 & 1.00 & 1.00 & 3.22 & 0.44 \\
\hline Mean & 12.75 & 5.00 & 3.47 & 0.65 & 1.00 & 1.30 & 4.33 & 1.11 \\
\hline
\end{tabular}


$\mathrm{N}=$ Number of samples, $\mathrm{Na}=$ Number of alleles (allelic richness), $\mathrm{Ne}=$ Effective number of alleles, $\mathrm{h}=$ genetic diversity, Arp $=$ Private allelic, I = Shannon's Information Index, PPL= Percentage of polymorphic loci, No. LComm Alleles (50\%): Number of Locally Common Alleles (frequency! $5 \%$ ) found in $50 \%$ or fewer population.

\section{Analysis of molecular variance (AMOVA)}

There was moderate degree of genetic differentiations among the tested Zymoseptoria tritici populations as revealed by Analysis of Molecular Variance (AMOVA) (PhiPT $=0.14 ; p=0.001$ ). The analysis showed that among populations genetic variation accounted for only $14 \%$ of the overall (3.93) genetic variations allocating the $86 \%$ for the within populations molecular diversity (Table 6). The analysis also confirmed the presence of considerable (3.14) gene flow ( $\mathrm{Nm}$ ) or gene migration (3.14) among the studied populations (Table 7).

Table 7

Analysis of molecular variance of 51 isolates of $Z$. tritici genotypes grouped in to population based on their geographical

\begin{tabular}{lcclllll}
$\begin{array}{l}\text { Source of } \\
\text { variation }\end{array}$ & DF & $\begin{array}{l}\text { Sum } \\
\text { square }\end{array}$ & $\begin{array}{l}\text { Mean } \\
\text { square }\end{array}$ & $\begin{array}{l}\text { Est. } \\
\text { variance }\end{array}$ & $\begin{array}{l}\text { Percent } \\
\text { variance }\end{array}$ & $\begin{array}{l}\text { Genetic } \\
\text { differentiation(PhiPT) }\end{array}$ & $\begin{array}{l}\text { P value } \\
\text { valuen }\end{array}$ \\
$\begin{array}{l}\text { Among } \\
\text { population }\end{array}$ & 3 & 29.101 & 9.700 & 0.54 & $14 \%$ & 0.14 & 0.001 \\
$\begin{array}{l}\text { Within } \\
\text { population }\end{array}$ & 47 & 159.527 & 3.394 & 3.39 & $86 \%$ & 0.14 & 0.001 \\
\hline Total & 50 & 188.627 & & 3.93 & $100 \%$ & & \\
\hline
\end{tabular}

\section{Measures of Genetic identity and Genetic distance between the populations}

Genetic grouping of populations based on Nei's genetic diversity showed that the pair wise genetic distance between the populations ranged from 0.36 to 0.82 and the maximum genetic distance (0.82) was observed between population from Kembata-Tembaro zone and population from Southwest Shewa zone (Table 7). The lowest genetic distance (0.36) was observed between populations of Silte and Southwest Shewa zone. On the other hand, Nei's genetic identity between the populations ranged from 0.43 to1.00 (Table 8 ).

Table 8

Pair- wise Population Matrix of Nei Genetic Distance

\begin{tabular}{|lllll|}
\hline Kembata- Tembaro & Hadiya & Silte & Southwest -Shewa & \\
\hline 0.000 & & & & $\begin{array}{l}\text { Kembata- } \\
\text { Tembaro }\end{array}$ \\
0.68 & & & Hadiya \\
0.54 & 0.000 & & & Silte \\
0.82 & 0.85 & 0.000 & & Southwest- \\
& 0.48 & 0.36 & 0.000 & Shewa \\
\hline
\end{tabular}

\section{Cluster analysis}

Cluster analysis of the $51 \mathrm{Z}$. tritici isolates revealed three major clusters (C1, C2 and C3,) with different hierarchical sub-groups. Most of the individuals (34 or 66.6\%) were assigned to C1. The lowest (3) number of individuals were assigned to sub-group C3 (Fig. 7). None of the clusters consisted of individuals of single population exclusively. The first cluster constituted isolates from Kembata- Temibaro (61.8\%), Silte (17.6\%), Hadiya (8.8\%) and Southwest Shewa (11.8). The second cluster consisted of isolates 
from Hadya (71.4\%), Southwest Shewa (21.4\%) and Silte (7.1\%). Whereas the third cluster comprised of isolates of Hadiya zone (Fig. 7).

\section{Principal coordinate analysis}

The principal coordinate analysis (PCOA) also confirmed the presence of poor population structure in the pathogen. It showed that the first three coordinates accounted for about $37.75 \%$ of the genetic variation. The first, second, and third principal coordinates explained about $15.46 \%, 12.27 \%$ and $10.02 \%$ of the gross variation, respectively. The PCoA analysis in the twodimensional plot displayed in Fig. 8 showed that isolates from different collection sites were clustered together. It is not cluster the isolates distinctly based on their geographical areas of sampling (Fig. 8) complementing the result of NJ cluster analysis.

\section{Population structure and admixture pattern}

Population structure analysis was carried out using STRUCTURE v 2.3.4 software based on Bayesian phylogenic method. The Structure harvester detected two picks (both at $\mathrm{K}=5$ and $\mathrm{K}=7$ (Fig. 9A). In such cases the most likely number of genetic clusters corresponds to the smallest value of $\mathrm{K}$ that captures the major structure in the data (Pritchard et al. 2000). Hence, the model detected the presence of five $(K=5)$ subpopulations. Based on this value, Clumpak result (bar plot) showed wide admixtures and hence there was no clear geographic origin-based on structuring of the populations (Fig. 9B).

\section{Discussion}

In the present study a diagnostic molecular marker specific to Zymoseptorai tritici was used for identification of the pathogen. The primer pair (ITS1 and JB446) target the ITS of ribosomal DNA region and amplified about 345 bp long products in all the 51 tested isolates indicating that all of them were likely to be the target pathogen. Similarly, Beck and Ligon (1995) used same primer pairs to differentiate Z. tritici isolates from other fungal species such as $S$. nodorum, $S$. glycines, S. passerinii, $P$. herpotrichchoides, P.aestiva, C. cereal, and D. sorokiniana. Moreover Diriba Guta et al. (2019) used the diagnostic markers to identify Z. tritici of Northern Ethiopia. The Authors also used similar diagnostic markers to determine $Z$. tritici isolates of Northern Ethiopia. The study confirmed that $Z$. tritici is a widespread and critical problem of wheat production in SNNP regional state of Ethiopia as well.

Analysis of the molecular diversity showed that the $Z$. tritici populations sampled from naturally infected wheat fields had high level of genetic diversity. In total, 439 bands were detected of which $92.71 \%$ where polymorphic. This figure is significantly higher than Kabbage et al. (2008) who reported $75 \%$ - $81 \%$ polymorphic bands at different population scales. This is because of primary source of inoculum which was due to airborne ascospores that would be dispersed uniformly within the field and long year's exposure of the pathogen populations to diverse resistance genes in the host materials.

Per locus, wide range of number of alleles ( 9 -14), gene diversity ( $0.73-0.88)$ and polymorphic information content $(0.70-0.87)$ were recorded indicating that all the microsatellite loci were highly informative, and useful genetic tools to disclose the genetic structure of the pathogen populations.

The PIC values provide discriminating power of a marker by taking into account not only the number of alleles at a locus but also relative frequencies of these alleles. Lower PIC values might be result of closely related genotypes and vice versa. Marker loci with an average number of alleles running at equal frequencies will have the highest PIC value. Markers polymorphism with > 0.5 are considered as highly informative, between 0.5 and 0.25 moderate and those with values below 0.25 are low informative (Smith, et al. 1997). In the current studies PIC value close to 1 suggests the presence of more alleles indicating polymorphism in that population which showed more uniform distribution of polymorphism bands among the isolates.

The average gene diversity (0.82) and number of alleles (12) per locus observed in the present study were significantly higher than the level reported by Berraies et al. (2013) who described a mean gene diversity and number of alleles of 0.49 and 2.5 alleles, respectively using 45 isolates of $Z$. tritici in Tunisia. The probable reason may be the number of SSR markers used in the present study is higher than they used and the genotype difference due to different in terms of locations of isolates collection

Page 10/19 
may create the variation. Gene diversity is the probability that two randomly chosen alleles from the population are different. The difference between the highest (0.88) and lowest (0.73) gene diversity indicates the presence of variability among $51 Z$. tritici isolates.

The observed gene diversity in the present study was also by far greater than the report of Owen et al. (1998) and Razavi and Hughes (2004b) who found an average gene diversity of 0.49 and 0.44 for 12 UK isolates and for 90 Canadian isolates, respectively. Moreover, the mean number of alleles (12) per locus we reported is significantly higher than the level reported by Medini and Hamza (2008) and Siah et al. (2018) who found an average of 2.5 and 4.2 alleles per locus, respectively. Whereas, the PIC (0.70 -0.80) detected in the present study equivalent to the report of by El-Wahsh et al., (2016) who described PIC values ranging from $0.51-0.83$ using 16 SSR markers.

The higher genetic diversity of the pathogen could be due to sexual reproductive biology or sexual recombination and spontaneous mutation. Moreover, geographical conditions, especially relative humidity in the air, and agricultural practices such as mono-cropping in places including Kembata-Tembaro and the Hadiya zones allow the annual incidence of the disease. This, by itself, can be effective in expanding, displacing, and creating diversity in the causal agent of the disease and can influence diversity of the pathogen (Berraies et al. 2013).

Moreover, population genetic variability analysis across the entire loci revealed higher genetic variability among the tested $Z$. tritici populations. This can be explained by higher mean number of alleles $(\mathrm{Na}=5.0)$, gene diversity $(0.65)$, effective number of alleles ( $\mathrm{Ne}=3.47$, Shannon's information index $(\mathrm{I}=1.3)$ and $100 \%$ percentage of polymorphism. Similarly, Dalvand et al. (2018) reported a mean number of alleles of 2.0, Nei's genetic diversity of 0.35 , Shannon's information index of 0.53 , and percentage of polymorphic loci value of $65 \%$. Similarly, high gene diversity values of 0.31 to 0.70 were reported for $Z$. tritici populations from USA (Gurung et al. 2011), Northern France (El Chartouni et al. 2011; Siah et al. 2018), and Tunisia (Boukef et al. 2012). The studied Z. tritici population showed higher gene diversity, and this could be attributed to sexual recombination, and long year's exposure of the pathogen populations to diverse resistance genes in the host materials which might have resulted in the pathogen evaluation (Siah et al. 2018).

Among tested populations, those of Kembata -Tembaro and Hadiya populations had more mean number of alleles ( $\mathrm{Na})$ and Shannon's information index (I) than those of Silte and Southwest Shewa populations. These differences could be attributed to the lower population sizes incorporated in the latter two populations.

Moreover, the populations showed a wide range of private alleles ranging from 0.67 (Kembata-Tembaro) - 3.22 (Silte populations), indicating that the populations possessed unique alleles and a certain level of independent evolution that allowed the maintenance of the private alleles at a population level. The private alleles reported in the present study were relatively lower than the private allele's values of 12,10, and 11 reported by (Kabbage et al. 2008). This might be because of the presence of high gene flow between in the current study areas.

Analysis of molecular variance (AMOVA) revealed that the populations showed statistically moderate (0.14) genetic differentiation rate where most (86\%) of the total genetic variation (3.93) was accounted by the within populations genetic variability, leaving only $14 \%$ for among populations. Similarly, in Canada Razavi and Hughes, (2004) reported a within and among population genetic variability of $88 \%$ and $12 \%$, respectively. In another study conducted by Linde et al. (2002) on samples from various countries including Switzerland and the United States, it was found that $77 \%$ was related to intra-population and $23 \%$ to inter-population diversity. Sexual recombination could be the major source of intra-population genetic variability (Siah et al. 2018). The lower inter-populations genetic variation could be due to the presence of strong gene flow (NM =3.14) among the study population through long distance movement of spores, seed exchange through marketing among neighboring zones and also transfer of STB infected seeds or straws from place to place by people (Schnieder et al. 2001; Consolo et al. 2009; Abrinbana et al. 2010).

The presence of low population differentiation rate and higher gene flow was evidenced by dendrogram results, principal coordinate analysis (PCoA) and population structure analysis in which the populations didn't sharply clustered based on their geographical areas of sampling. Population structure analysis confirmed that the populations were composed of five sub-

Page $11 / 19$ 
populations with higher degrees of admixture. Similarly, unstructured population was reported for Z.tritici populations of Tunisia (Boukef et al. 2012). To the contrary, El Chartouni et al. (2011) and Siah et al. (2018) in northern France and Abrinbana et al. (2010) in Iran reported a 5 - 6 distinct clustering of the $Z$. tritici populations based on geographical origin of the samples.

\section{Conclusion}

In the present study, a total of 51 Z. tritici isolates from five zones of South and southwestern parts of Ethiopia were profiled using molecular tools. The diagnostic marker that target the ITS region of rDNA amplified an expected fragment size from all the tested isolates. All the used markers were found to be highly informative with PIC information contents ranging from $0.7-0.87$ ) and gene diversity of $0.73-0.88$, confirming that they are useful genetic tools to depict the molecular diversity and population structure of the pathogen populations.

The high within population's gene diversities $(0.57$ to 0.73$)$ in all the populations indicates that areas included in the present study are very appropriate for multi-location germplasm screening, the pathogen dynamics over time and also host-pathogen interactions. Among the tested populations, those from Kembata-Tembaro and Hadiya showed relatively higher gene diversity and these could be suitable locations if site selection for resistance evaluation is required. Moreover, the Z. tritici populations didn't genetically cluster according to their geographical origin due to the presence of high gene flow, and they share genetic background from five sup populations with greater degrees of admixture.

\section{List Of Abbreviations}

AMOVA

CTAB

CSA

DArT

ITS-rDNA

PCoA

PDA

SDS

SLB

SPL

SSR

STB

UPGMA

YSB
Analysis of molecular Variance

Cetyl trimethylammonium bromide

Central Statistical Agency

Diversity Array Technology

Internal transcribed spacer ribosomal DNA

Principal coordinates Analysis

Potato dextrose agar

Septoria Disease Severity

Septoria Leaf Blotch

Scientific Phytopathological Laboratory

Simple Sequence Repeats

Septoria tritici Blotch

Unweight Pair Group Methods with Arithmetic average

Yeast extracts Sucrose Broth

\section{Declarations}

\section{Acknowledgement}

First and foremost, I want to express my gratitude to the Almighty God for bringing me this far in my academic endeavors. 
I'd like to express my gratitude to Dr. Teklehaimanot Hailesilassie, my thesis advisor. I am indebted to him for his invaluable remarks and recommendations in completing this thesis. I'd want to express my heartfelt gratitude to my advisor, Dr. Kassahun Tesfaye, for all of his assistance. I'd like to convey my heartfelt gratitude to Tilahun Mekonnen for his unwavering support, constructive criticism, patience, drive, passion, and vast knowledge. I attribute every aspect of this study's strength to my advisor, Tilahun Mekonnen, and any flaws to me. My heartfelt thanks also go to Obssi Dessalegn for his patience and sound advice during the thesis work.

I'd also like to express my gratitude to Addis Ababa University's Institute of Biotechnology for providing me with the opportunity to enroll in the MSc. program in Biotechnology. My heartfelt gratitude also goes out to the Ethiopian Institute of Agricultural Research for allowing me to participate in the study. I'm also appreciative for the laboratory space and facilities provided by the National Agricultural Biotechnology Research Center in Holetta.

Many thanks to Zewdinesh Damtew for her expert help in the molecular lab. We had a great time at the lab. Thank you very much for the advantages I received from her as a result of our strong friendship.

I would like to express my warm thanks and regards to my dear family Eleni Yalew, Molla Kassia, Fentaye Tareke, and others for their frenziedly love and hope for my pleasure and better life. Thank you very much for your love and support

Authors' contributions The study's inception and design were aided by all of the writers. Messele Molla was in charge of sample collection, data collecting, and analysis. All co-authors contributed to the interpretation of the data, the preparation and revision of the earlier version of the paper, and the final approvals.

Funding Ethiopian Institute of Agricultural Research and Addis Ababa University collaborated on the project.

\section{Compliance with ethical standards}

Conflict of interest: The authors disclose that they do not have any competing interests.

Ethical approval: There are no human or animal participants in this study.

Ethical responsibility: The data in this manuscript is unique to us and has never been published before. Other people's work and words have been acknowledged appropriately.

Author agreement/ declarations: We check that all named authors have read and approved the paper, and that no other individuals who meet the criteria for authorship but are not listed have done so. We also affirm that the manuscript's authorship order has been approved by all of us.

\section{References}

1. Abera Takele A, Kassa B, Getaneh W, Ab, and Endale Hailu (2015) Status of wheat Septoria leaf blotch (Septaria tritici Roberge in Desmaz) in south westWestern Shewa zones of Oromiya regional state, Ethiopia. Research in Plant Sciences. 3 : 43-48

2. AbrehamTadesse (2008) Increasing crop production through improved plant protection. PPSE 1:19-22

3. Abrinbana M, Mozafari J, Shams-bakhsh M, Mehrabi R (2010) Genetic structure of Mycosphaerella graminicola populations in Iran. Plant Pathol 59:828-838

4. Alemar Said and and Temam Hussien (2016) Effect of SeptoriaTrtici Blotch (Septoria tritici) on Grain Yield and Yield Components of Bread Wheat. Agricultural biology 6:2224-3208

5. Beck JJ, Ligon JM (1995)Polymerase chain reaction assays for the detection of Stagonosporanodorum and Septoria triticin wheat.Phytopathology. 85:319-324

6. Berraies S, Gharbi MS, Belzile F, Yahyaoui A, Hajlaoui MR, Trifi M, Jean M, Rezgui S (2013) High genetic diversity of Mycospaherella graminicola (Zymoseptoria tritici) from a single wheat field in Tunisia as revealed by SSR markers. African

Page 13/19 
journal of biotechnol 12:2254-2259

7. Boukef S, McDonald BA, Yahyaoui A, Rezgui S, Brunner PC (2012) Frequency of mutations associated with fungicide resistance and population structure of Mycosphaerella graminicola in Tunisia. Eur J Plant Pathol 132:111-122

8. Consolo VF, Albani CM, Bero'n CM, Salerno GL, Cordo CA (2009) A conventional PCR technique to detect Septoria triticiin wheat seeds. Australas Plant Pathol 38:222-227

9. Czembor PC, Arseniuk E (1999) Study of Genetic Variability Among Monopycnidial and Monopycnidiospore Isolates Derived from Single Pycnidia of Stagonospora ssp. and Septoria tritici with the use of RAPD-PCR, MP-PCR and rep-PCR Techniques. J Phytopathol 147:539-546

10. Dalvand M, Zafari D, Pari MS, Roohparvar R, Tabib SM (2018) Studying Genetic Diversity in Zymoseptoria tritici, Causal Agent of Septoria Tritici Blotch, by Using ISSR and SSR Markers. Journal of Agricultural science 20:1307-1316

11. Dixon J, Nalley L, Kosina P, La Rovere R, Hellin J, Aquino P (2006) Adoption and economic impact of improved wheat varieties in the developing world. Journal of Agricultural science 144:489-502

12. Earl DA, Von Holdt BM (2012) STRUCTURE HARVESTER: a website and program for visualizingSTRUCTURE output and implementing the Evanno method. Conservation genetics resources 4:359-361

13. El Chartouni L, Tisserant B, Siah A, Duyme F, Leducq JB, Deweer C, Fichter-Roisin C, Sanssené J, Durand R, Halama P, Reignault P (2011) Genetic diversity and population structure in French populations of Mycosphaerella graminicola. Mycologia 103:764-774

14. El-Wahsh SM, El-Raee YZ, Emeran AA, Mashaal SF, Arafa RA (2016) Genetic diversity of rice blast fungus populations (Pyriculariagrisea) using molecular markers. Journal of Agricultural Chemistry and Biotechnology 7:57-65

15. Evanno G, Regnaut S, Goudet J (2005) Detecting the number of clusters of individuals' usingthe software STRUCTURE: a simulation study. Mol Ecol 14:2611-2620

16. Eyal Z, Scharen AL, Prescott JM, Ginkel Mv (1987) The Septoria Diseases of Wheat: Concepts and methods of disease management. CIMMYT 52:17

17. FAOSTAT (2018) FAOSTAT statistical database. (Accessed 16 July 2018)

18. Gilchrist L, Dubin HJ (2002) Septoria diseases of wheat. Bread Wheat Improvement, and Production. FAO Plant Production and Protection Series, No. 30

19. Gurung S, Goodwin SB, Kabbage M, Bockus WW, Adhikari TB (2011) Genetic differentiation at microsatellite loci among populations of Mycosphaerella graminicola from California, Indiana, Kansas, and North Dakota. Phytopathology 101:12511259

20. Kabbage M, Leslie JF, Zeller KA, Hulbert SH, Bockus WW (2008) Genetic diversity of Mycosphaerella graminicola, the causal agent of Septoria tritici blotch. Journal of Agricultural Science and Technology 2:1-8

21. Kopelman NM, Mayzel J, Jakobsson M, Rosenberg NA, Mayrose I (2015) CLUMPAK: aprogram for identifying clustering modes and packaging population structure inferencesacross K. Molecular ecology resources 15:1179-1191

22. Letta T, Maccaferri M, Badebo A, Ammar K, Ricci A, Crossa J, Tuberosa R (2013) Searching for novel sources of field resistance to Ug99 and Ethiopian stem rust races in durum wheat via association mapping. Theor Appl Genet 126:12371256

23. Linde CC (2002) Population Structure of Mycosphaerella graminicola: From Lesions to Continents. Phytopathology. 92:946-955

24. Liu KJ, Muse SV (2005) Power Marker:an integrated analysis environment for genetic marker analysis. Journal of bioinformatics21:2128-2129

25. Medini M, Hamza S (2008) Pathotype and molecular characterization of Mycosphaerella graminicola isolates collected from Tunisia, Algeria, and Canada. Journal of Plant Pathology 3:65-73

26. Mekonnen T, Haileselassie T, Kaul T, Sharma M, Geleta A, Tesfaye K (2019) Molecular screening of Zymoseptoria tritici resistance genes in wheat (Triticum aestivum $\mathrm{L}$ ) using tightly linked simple sequence repeat markers. Eur $\mathrm{J}$ Plant Pathol 155:593-614. https://doi.org/10.1007/s10658-019-01795-y

Page 14/19 
27. Mengistu H, Getaneh W, Yeshi A, Rbka D, Ayele B (1991) Wheat pathology research in Ethiopia. In: In: Hailu G, Tanner DG, Mengistu H (eds) Wheat Research in Ethiopia: a Historical Perspective. IAR/CIMMYT, Addis Ababa, pp 173-217

28. Nei M (1973) Analysis of gene diversity in sub-divided populations. Proceedings of the National Academy of Sciences. 70 : 3321-3323

29. Owen PG, Pei M, Karp A, Royle DJ, Edwards KJ (1998) Isolation and characterization of microsatellite loci in the wheat pathogen Mycosphaerella graminicola. Mol Ecol 7:1611-1612

30. Pavel AB, Vasile $\mathrm{Cl}$ (2012) PyElph-a software tool for gel images analysis and phylogenetics. BMC Bioinformatics 13:1-6

31. Perrier X, Jacquemoud-Collet JP (2006) DARwin software. http://darwin. cirad. fr/darwin (accessed 1 March 2013)

32. Ponomarenko A, Goodwin SB, Kema GHJ (2011) Septoria tritici blotch (STB) of wheat. Plant Health Instructor. https://doi.org/10.1094/PHI-I-2011-0407-01

33. Pritchard JK, Stephens M, Donnelly P (2000) Inference of population structure using multilocus genotype data. Genetics 155:945-959

34. Razavi M, Hughes GR (2004) Molecular variability of Mycosphaerella graminicola as detected by RAPD markers. Journalof phytopathology. 152:543-548

35. Schnieder F, Koch G, Jung C, Verreet JA (2001) Genotypic diversity of the wheat leaf blotch pathogen Mycosphaerella graminicola (anamorph) Septoria tritici in Germany European Journal of Plant Pathology.107:285-290

36. Sebei A, Harrabi M (2008) Assessment of virulence variability in Septoria tritici isolates and resistance of selected durum wheat cultivars. Tunisian Journal of Plant Protection 3:11

37. Shaner G (1981) Effect of environment on fungal leaf blights of small grains. Annu Rev Phytopathol 19:273-296

38. Siah A, Magnin-Robert M, Randoux B, Choma C, Rivière C, Halama P, Reignault $P$ (2018) Natural agents inducing plant resistance against pests and diseases. In Natural Antimicrobial Agents Pp. 121-159). Springer,Cham

39. Smith JSC, Chin ECL, Shu H, Smith OS, Wall SJ, Senior ML, Mitchell SE, Kresovich S, Ziegle J (1997) An evaluation of the utility of SSR loci as molecular markers in maize (Zea mays L.): comparisons with data from RFLPs and pedigree.

Theor.Appl.Genet95:163-17Steinberg, G. (2015). Cell biology of Zymoseptoria tritici: Pathogen cell organization and wheat infection. FungalGenetics and Biology. 79: 17-23

40. Teklay, Abebe, Muez Mehari and Muruts Legesses (2015) Field response of wheat genotype to Septoria tritici blotch in tigray. Journal of Natural Sciences Research 5(1):2224-3186

41. Tilahun Mekonnena T, Haileselassiea, Goodwinb SB, Kassahun, Tesfaye (2020) Genetic diversity and population structure of Zymoseptoria tritici in Ethiopia as revealed by microsatellite marker. Fungal Genetics and Biology. 141: 103413

42. White h, Peakall R (2015) GENALEX 6.502: Genetic analysis in Excel. Population genetics of tware for teaching and research. Molecular Ecology Notes 6:288-295

43. Yeh FC, Yang R (1999) POPGENE VERSION 1.31: Microsoft Window-based Freeware for Population Genetic Analysis.Department of Renewable Resources University of Alberta, Canada. Pp:1-29

44. Zadoks JC, Chang TT, Konzak CF (1974) A decimal code for the growth stages of cereals. Weed Researc. 14

\section{Figures}




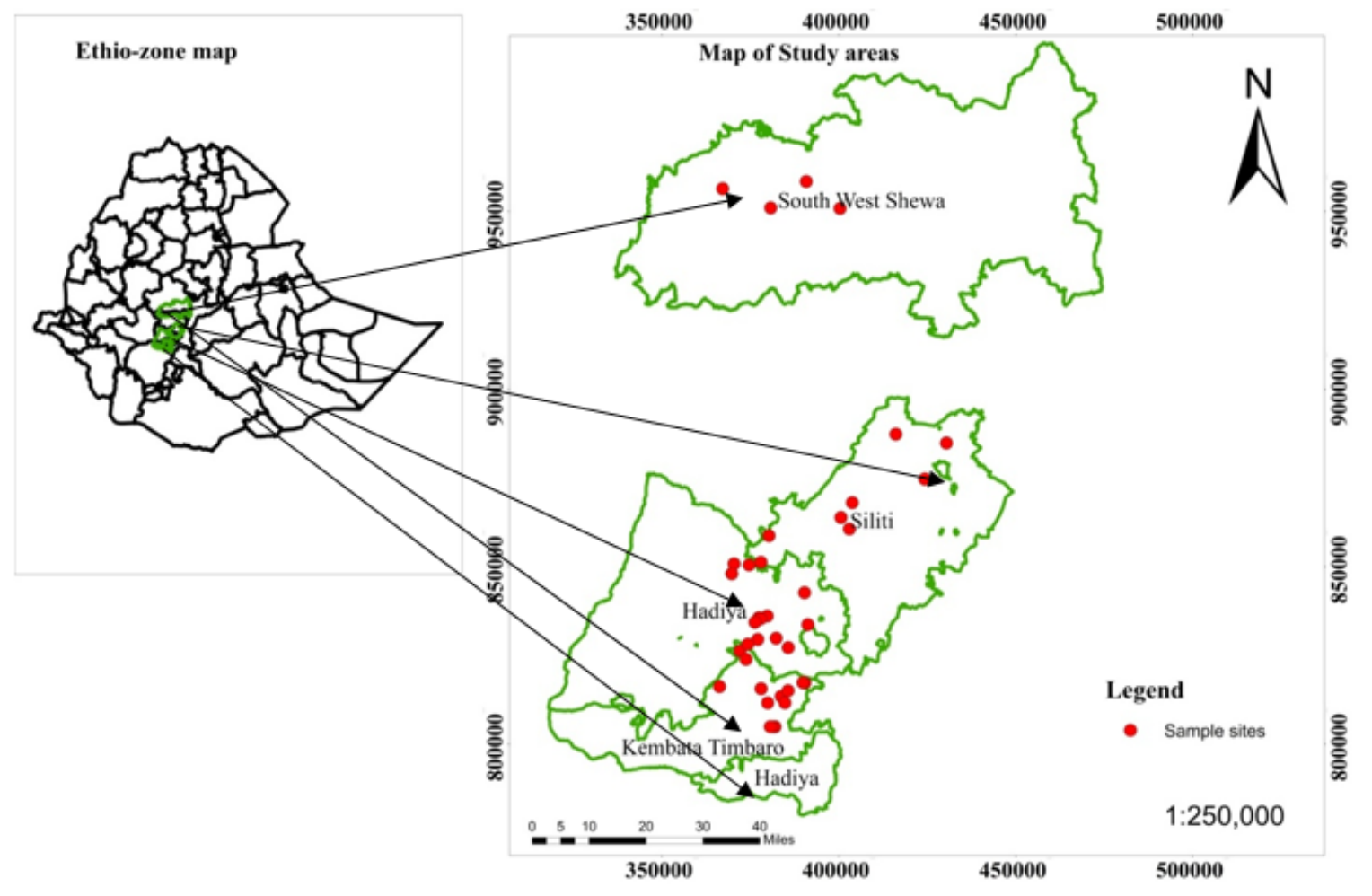

Figure 1

Map of Ethiopia (on the left) with the four zones (on the right) representing the four Zymoseptoria tritici populations. The map was constructed using geographic coordinates and elevation data gathered from each collection site using the global positioning system (GPS). 


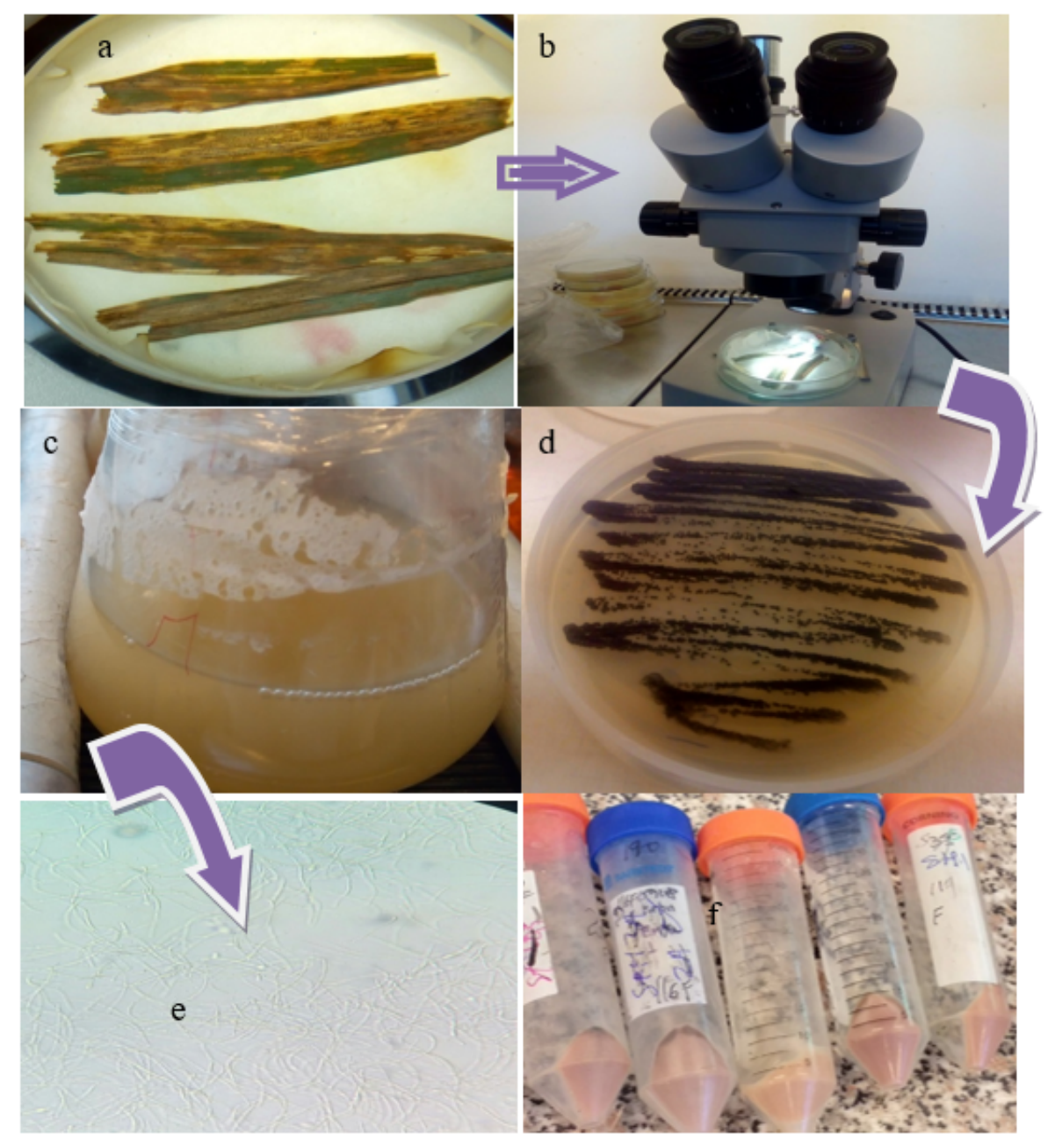

\section{Figure 2}

Z.ymoseptoria tritici isolation procedure. a) $10 \mathrm{~cm}$ long STB symptomatic leaves on samples on wet filter paper in Petri dish b) transferring oozing drops to PDA observing using stereoscopic dissecting microscope under sterile cabinet, c) Pure $Z$. tritici culture on PDA ready for multiplication, d) Z. tritici spores under 10x magnification objectives, e) Spore multiplication in YSB, and f) Spore pellets recovered through centrifugation.

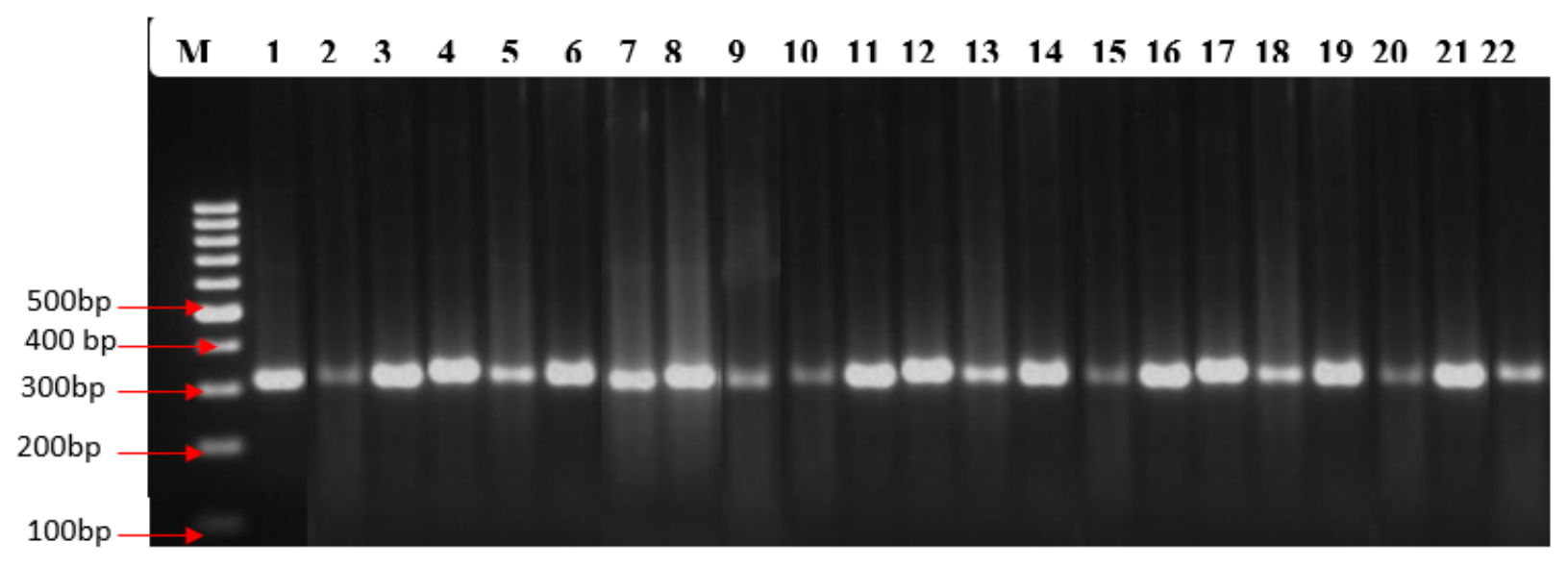

Figure 3 
PCR products for molecular diagnostics of Zymoseptoria tritici. $\mathrm{M}=$ molecular marker, number 1 up to 22 Z. tritici isolated samples

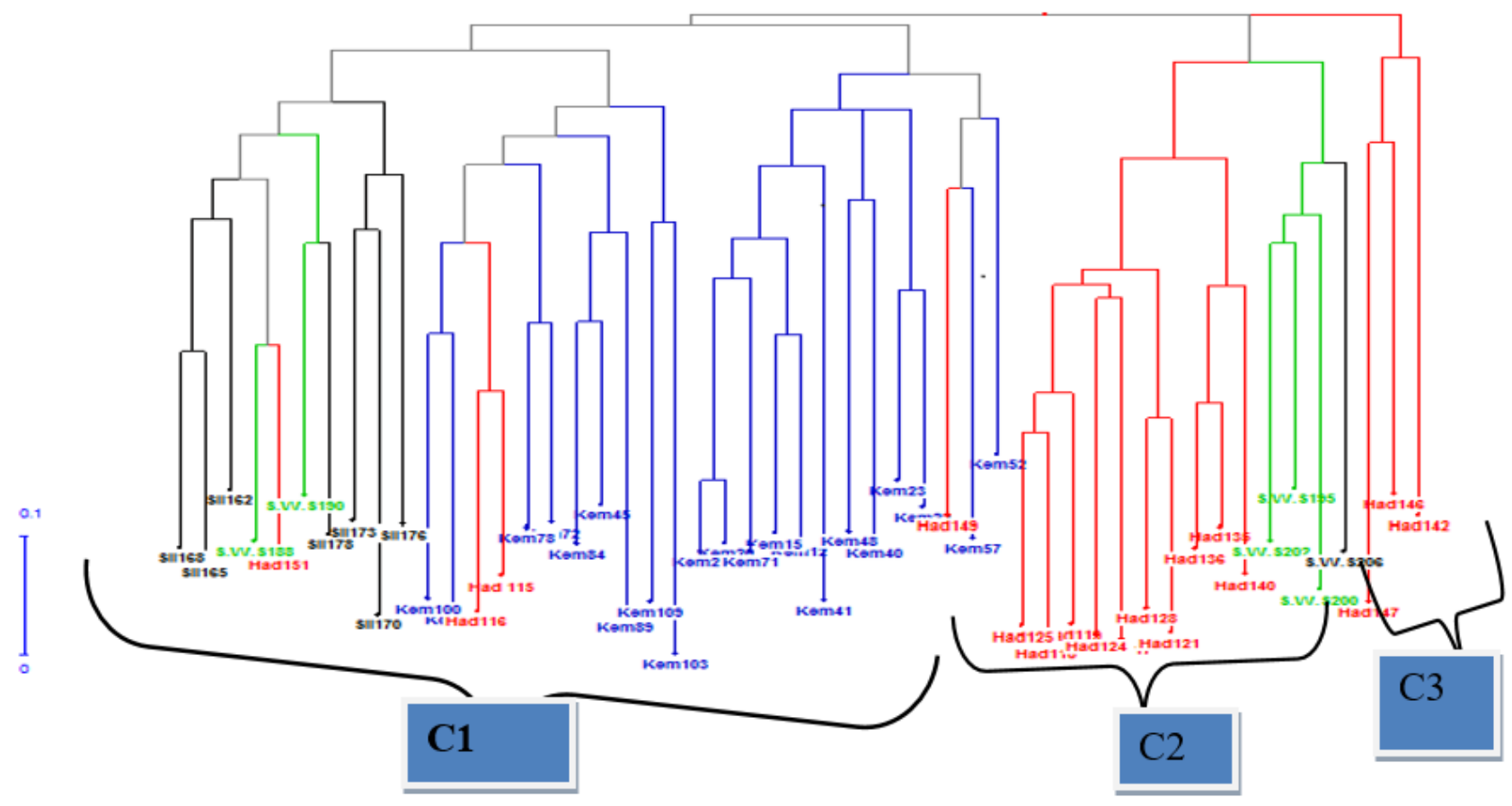

\section{Figure 4}

Neighbor-joining tree for 51 isolates of $Z$. tritici based on Jaccard coefficient of similarity with 1000 replication as revealed by 9 SSR molecular markers. Kem stands for isolates from Kembata-Tembaro zone, Had refers to Hadiya isolates, S.W.S stands for South West Shewa collections and Sil stands for Silte zone collections.

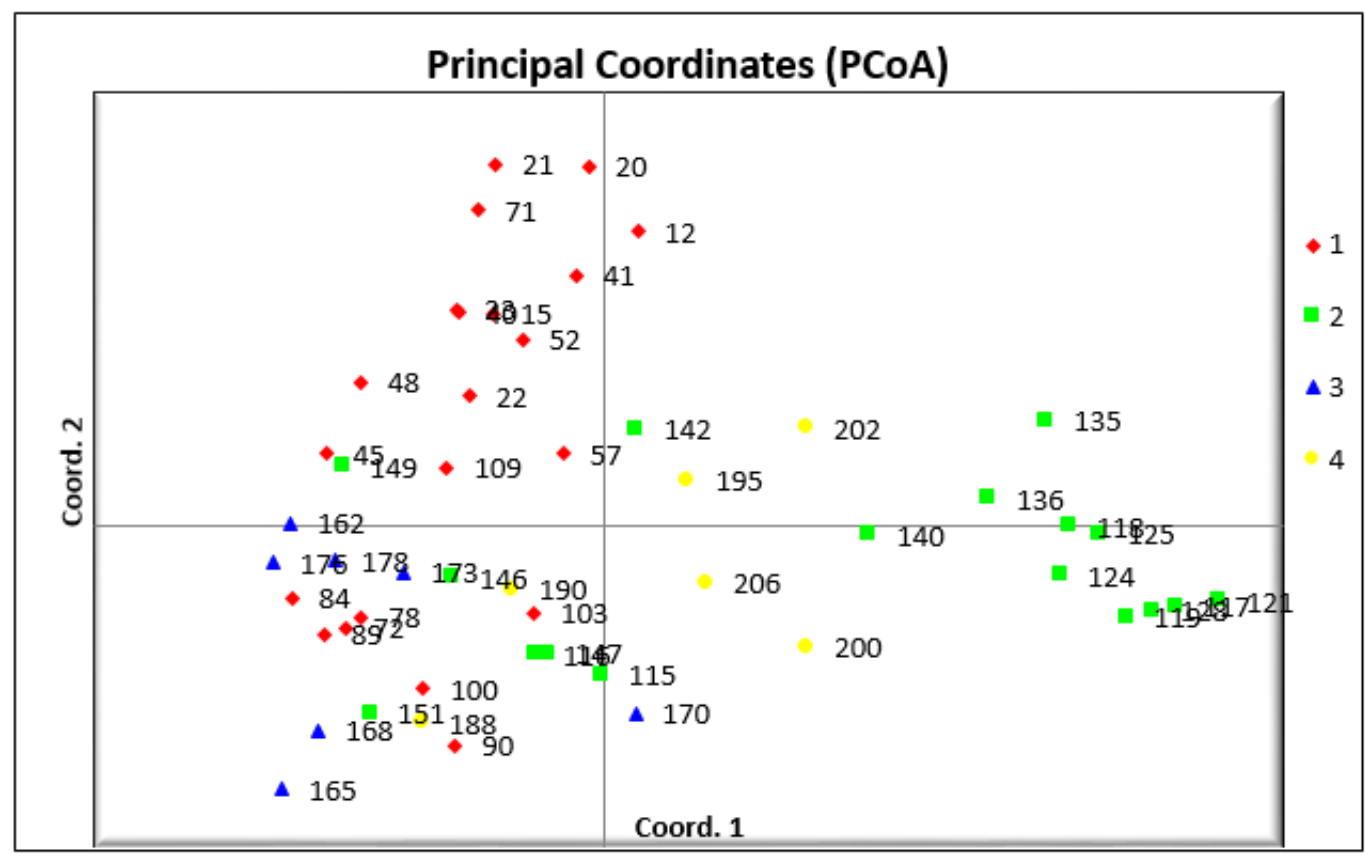

Figure 5 
Two dimensional plot of PCoA analysis of 51 Z. tritici isolates and four Population (1= Kembata- Tembaro, $2=$ Hadiya, $3=$ Silte and 4 = Southwest Shewa populations) based on 9 SSR markers. Samples coded with the same symbol and colors belong to the same population.
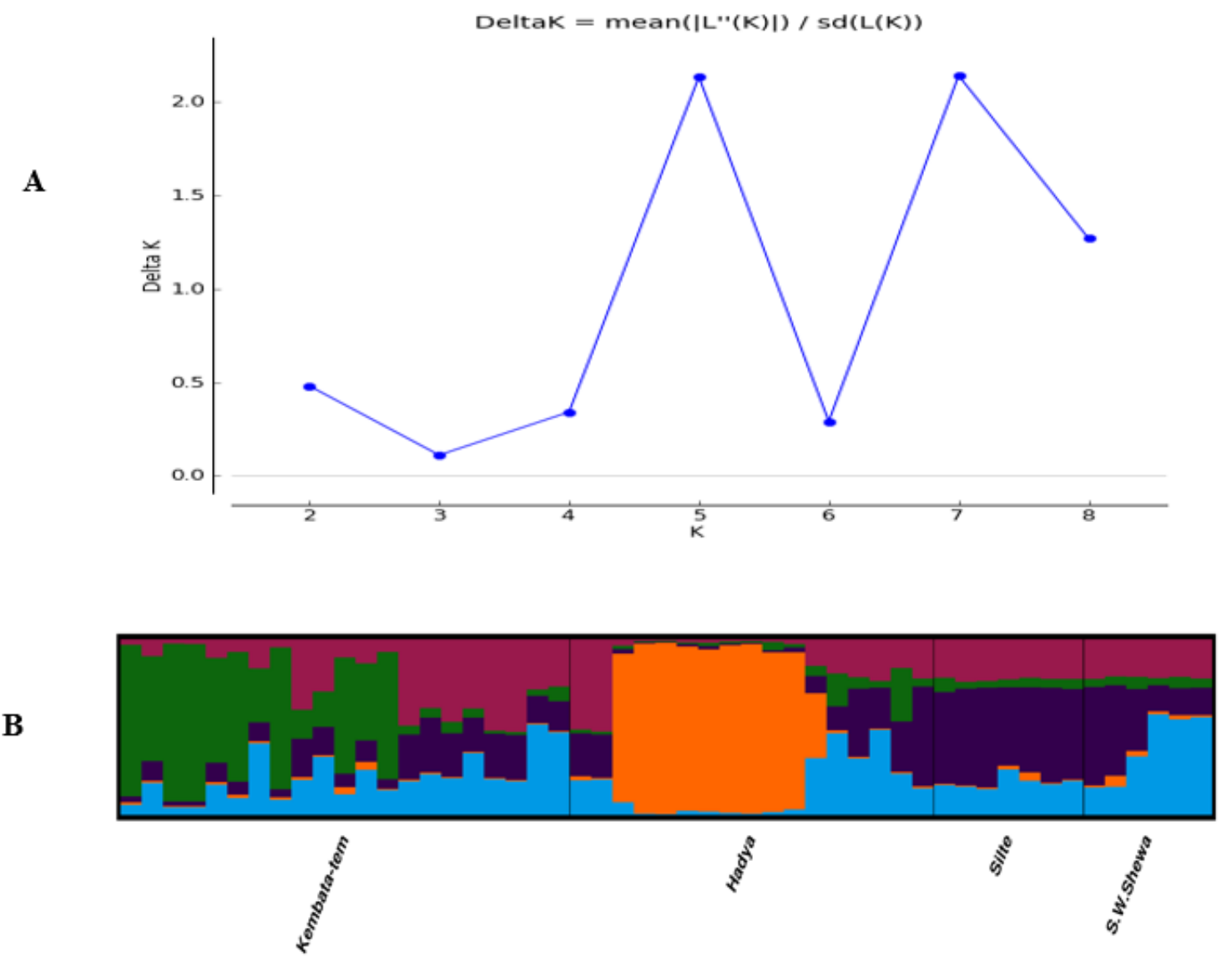

\section{Figure 6}

Inferred population structure of 51 Z. tritici isolates A) number of population subgroups based on Evano et al. (2005) and B) Estimated population structure for $\mathrm{K}=5$ according to geographical locations. The different colures represent genetic groups or sub-populations designated by Structure Harvester: the x-axis represents individual samples and y-axis represents the proportion of ancestry to each cluster. 